Elsevier required licence: (C) 2018. This manuscript version is made available under the CC-BY-NC-ND 4.0 license http://creativecommons.org/licenses/by-nc-nd/4.0/ 


\title{
Barriers to big data analytics in manufacturing supply chains: A case study from Bangladesh
}

\begin{abstract}
Recently, big data (BD) has attracted researchers and practitioners due to its potential usefulness in decision-making processes. Big data analytics (BDA) is becoming increasingly popular among manufacturing companies as it helps gain insights and make decisions based on BD. However, there many barriers to the adoption of BDA in manufacturing supply chains. It is therefore necessary for manufacturing companies to identify and examine the nature of each barrier. Previous studies have mostly built conceptual frameworks for BDA in a given situation and have ignored examining the nature of the barriers to BDA. Due to the significance of both $\mathrm{BD}$ and $\mathrm{BDA}$, this research aims to identify and examine the critical barriers to the adoption of BDA in manufacturing supply chains in the context of Bangladesh. This research explores the existing body of knowledge by examining these barriers using a Delphi-based analytic hierarchy process (AHP). Data were obtained from five Bangladeshi manufacturing companies. The findings of this research are as follows: i) data-related barriers are most important, ii) technology-related barriers are second, and iii) the five most important components of these barriers are a) lack of infrastructure, b) complexity of data integration, c) data privacy, d) lack of availability of BDA tools and e) high cost of investment. The findings can assist industrial managers to understand the actual nature of the barriers and potential benefits of using BDA and to make policy regarding BDA adoption in manufacturing supply chains. A sensitivity analysis was carried out to justify the robustness of the barrier rankings.
\end{abstract}

Keywords: AHP; Big data analytics; Barriers to BDA; Delphi; Information and communication technology (ICT); Manufacturing supply chains.

\section{Introduction}

Today, the effective and efficient use of big data analytics (BDA) by manufacturing companies is considered a key success factor for businesses in the global market (Minelli et al., 2013; Wang et al., 2015; Wang \& Hajli, 2017). Meanwhile, manufacturing companies are facing trouble in handling big data (BD) due to rapidly increasing global data, data complexity, data privacy, etc. In addition, the amount of global data has increased rapidly due to advances in 
information and communication technology (ICT) such as Web 2.0 and the internet of things (IoT) (Waller \& Fawcett, 2013; Wang et al., 2016a, b). Due to these advancement, there are many opportunities to develop BDA tools and apply BD techniques to manufacturing supply chains. Therefore, BDA may contribute to manufacturing supply chains in making informed decisions, managing and mitigating risks, improving operational procedures, introducing new products to the market, conducting market analyses for particular products, and so on (Schoenherr \& Speier-Pero, 2015; Zhong et al., 2016).

The concept of BDA is not completely new, and was derived from internet corporations like Google, Yahoo, Amazon and Netflix. These corporations analyse actual consumer activity data in their decision-making processes (Gandomi \& Haider, 2015; Tsai et al., 2015). Many manufacturing companies want to use BD to improve the performance of their supply chains. However, they may fail due to lack of understanding of BDA, lack of BD infrastructure, or other issues present in supply chains.

Investigating barriers to BDA in manufacturing supply chains is vital in today's technologically advanced world. A proper investigation on barriers to BDA can facilitate manufacturing companies to build more effective strategies. There are few studies on the barriers to BDA in manufacturing supply chains. Alharthi et al. (2017) presented a qualitative analysis of barriers to using BDA. Malaka and Brown (2015a) qualitatively investigated the challenges of BDA for the South African telecommunications industry. Still, there is lack of comprehensive investigation on barriers to adopt BDA for manufacturing supply chain in the context of Bangladesh.

Bangladesh is a developing country. The rapid development of its manufacturing sector necessitates the use of BDA tools in its supply chains if it is to compete globally. The use of BDA tools in manufacturing supply chains may help to improve business efficiency (Dessureault, 2016) and gain competitive advantage. Bangladeshi manufacturing companies are facing difficulties in the adoption of BDA tools due to the presence of various barriers. It is imperative to quantitatively investigate the barriers to using BDA in manufacturing supply chains in the context of Bangladesh so that industrial managers can be guided in its implementation. A quantitative analysis of BDA barriers will assist them in formulating 
strategies for BDA implementation. As such, this research focuses on the following research questions:

1. What are the barriers to the adoption of BDA in manufacturing supply chains in the context of Bangladesh?

2. How can industrial managers examine specific barriers in a quantitative way?

3. Can the results help industrial managers formulate strategies to implement BDA?

To address the above research questions, this research has the following objectives:

a) To identify barriers to the use of BDA in the manufacturing supply chains of Bangladesh.

b) To examine the barriers in a quantitative way using a Delphi-based analytic hierarchy process (AHP) approach.

c) To suggest some managerial implications for the use of BDA in manufacturing supply chains.

To achieve the aims, a Delphi-based AHP technique was employed to select significant BDA barriers. The Delphi technique is a rational research technique in which data is extracted from structured questionnaires given to a group of experts (Gordon, 2009; Lummus et al., 2005; Seuring \& Müller, 2008). It is a dynamic method of obtaining research data in which experts share their knowledge, opinions and experience until they reach a mutual consensus (Dalkey \& Helmer, 1963; Linstone \& Turoff, 2002). The AHP system was initiated by Thomas Saaty in 1980. It can rank categories (in this case, barriers) in an easy and powerful way (T L Saaty, 1988). The reason for choosing the AHP method in this study is that i) it is very simple to use, ii) it requires few calculations and has high applicability in multi-criteria decision-making processes (Paleie \& Lalic, 2009; Saaty, 2008; Shahin \& Mahbod, 2007).

The rest of the paper is organised as follows: Section 2 reviews the related literature. Section 3 presents the proposed approach employing AHP and Delphi. Section 4 illustrates an application of the solution. Section 5 discusses the results. Section 6 performs sensitivity analysis. Section 7 gives the managerial implications of this research. Section 8 concludes the paper. 


\section{Literature review}

In this section, we discuss $\mathrm{BD}$ and $\mathrm{BDA}$, their applications in manufacturing supply chains, barriers to using BDA in manufacturing supply chains, and the research methodology.

\subsection{Big Data}

Big data is used to describe datasets that are very complex in nature, large, and unable to be handled by traditional applications (M. Chen, Mao, \& Liu, 2014; Dessureault, 2016). Massive volumes of data are produced by human activities, manufacturing activities and ICT. Therefore, $\mathrm{BD}$ in the manufacturing industry handles large amounts of data derived from various manufacturing activities. Such data cannot be handled by conventional data processing systems (Davenport \& Dyché, 2013; George, Haas, \& Pentland, 2014). To handle BD, it is necessary to develop a set of techniques and technologies to structure unstructured data.

The definition of BD made by the 'Gartner Group' is widely applicable. They define BD as " $3 \mathrm{Vs}$ ": volume, variety and velocity. The term volume relates to unstructured data that is hard to collect in a structured way and is generally infinite. Such unstructured datasets require new technologies and BDA tools to store, analyse and present them in structured ways. Variety refers to the fact that data comes from various sources like the internet, manufacturing operations logs, event logs, consumer feedback on social media, previous work notes, dimensions of various products, prices of products and product target markets. It can be a complex task to accumulate such data in a structured way. Finally, data velocity means that the data is generated and recorded continuously in real-time. It is challenging to handle such kinds of data using conventional techniques (Gartner, 2013; Sagiroglu \& Sinanc, 2013). Several definitions exist for BD as reported in literature. For example, Beyer and Laney, (2012) define big data as a high volume, high velocity and high variety data that is used in decision making process and required innovative techniques to manage them. Sun et al., 2015) have stated that BD is a special type of data having large size and is unable to be stored, handled and analyzed via conventional system together with anonymous source, diverse dimensions and its relationship cannot be measured easily due to its complexity and dynamic nature. Therefore, to capture, manage and analyze data, it requires a special type of analytical technique. 


\subsection{Big Data Analytics and its applications in manufacturing supply chains}

BDA is an advanced analytical technique of data management where datasets are aggregated in a structured way. These advanced analytical techniques can help in creating meaningful insights that aid complex decision making (Gandomi \& Haider, 2015; Tsai et al., 2015; Wang et al., 2015). Many world class business organizations including pharmaceutical, garments, automotive, retails, healthcare, financial services are using BDA tools to minimize processing flaws, increase efficiency, increase productivity, improve production quality and save time and money. The application of BDA tools to manufacturing supply chains is also an important issue in today's business world.

The importance of $\mathrm{BD}$ and $\mathrm{BDA}$ in manufacturing supply chains is also highlighted in various scholarly articles such as Waller and Fawcett (2013). In their research, Waller and Fawcett (2013) stated that qualitative and quantitative analysis can help resolve supply chain-related problems by considering data quality and data availability issues. Bi and Cochran (2014) showed that BDA can act as a critical technology used to manage and integrate data in data management processes, which can help to improve manufacturing performance. They tried to connect the IoT and $\mathrm{BD}$ to manufacturing systems to minimise bottlenecks by developing forecasting techniques. Chae (2015) developed a conceptual framework to observe current trends in supply chain management by using Twitter. Singh et al. (2017) developed a social media data analytics methodology for analysing supply chain and logistics operations for food industries. Li et al. (2015) investigated the potential scope of using BD to manage product lifecycles. Gandomi and Haider (2015) showed how BD predictive analytics helps to measure the sustainability of supply chains. Hazen et al. (2016) determined a relationship between sustainable supply chain management and $\mathrm{BD}$ predictive analytics.

The next section discusses the barriers to the use of BDA in manufacturing supply chains.

\subsection{Barriers to BDA in manufacturing supply chains}

In the era of $\mathrm{BD}$, manufacturing companies have started to adopt $\mathrm{BDA}$ tools to facilitate and sustain business in the global market. However, they face hurdles in the adoption of BDA. These hurdles should be investigated for adoption of BDA tools to minimize risks, improve productivity, quality control, etc. We therefore examined the existing literature using keywords 
like barriers to BDA in manufacturing supply chains; barriers to the use of BDA, challenges of using BDA, hurdles of using BDA in supply chains; supply chains and BDA, etc. All of these keywords were used to identify literature on BDA in various journal databases such as Science Direct, Scopus, SciSearch, Emerald, Taylor \& Francis, ISI web-of-science (WoS). This literature search revealed that several researchers tried to investigate the barriers in BDA adoption. As for example, Alharthi et al. (2017) investigated barriers to BDA by qualitative analysis, Malaka and Brown (2015a) used a qualitative framework to investigate the challenges of using BDA in the South African telecommunications industry, Hilbert (2016) used a conceptual framework to review articles relevant to the threats and opportunities of using BDA for international development.. From the literature search, we identified the nine most important barriers to the use of BDA in manufacturing supply chains. We also considered six barriers relevant to the Bangladeshi manufacturing industry context. Several discussion sessions were conducted with industrial managers to confirm the validity of the identified barriers. We categorised the identified barriers into four groups with the help of feedback from a group of experts. The identified barriers are presented in Table 1. Existing studies on BD and BDA are summarised in Table 2. 
Table 1: Barriers to using BDA in manufacturing supply chains

\begin{tabular}{|c|c|c|c|}
\hline Main barriers & Sub-barriers & A brief explanation of each barrier & Relevant literature \\
\hline \multirow[t]{3}{*}{$\begin{array}{l}\text { A. Technology- } \\
\text { related barriers } \\
\left(\mathrm{DAB}_{1}\right)\end{array}$} & $\begin{array}{l}\text { 1. Lack of availability of } \\
\text { specific BDA tools }\left(\mathrm{DAB}_{11}\right)\end{array}$ & $\begin{array}{l}\text { In manufacturing supply chains, lack of } \\
\text { appropriate BDA tools can slow down } \\
\text { smooth production. }\end{array}$ & This paper \\
\hline & $\begin{array}{l}\text { 2. Lack of infrastructural } \\
\text { facility }\left(\mathrm{DAB}_{12}\right)\end{array}$ & $\begin{array}{l}\text { Most of the present technologies are still } \\
\text { unable to meet current infrastructure } \\
\text { requirements }\end{array}$ & $\begin{array}{l}\text { (Alharthi et al., } \\
\text { 2017; Malaka \& } \\
\text { Brown, 2015; } \\
\text { Trelles et al., 2011) }\end{array}$ \\
\hline & $\begin{array}{l}\text { 3. Lack of interest in } \\
\text { implementing new } \\
\text { technology }\left(\mathrm{DAB}_{13}\right)\end{array}$ & $\begin{array}{l}\text { Existing technology for BD management } \\
\text { in manufacturing supply chains is } \\
\text { expensive. }\end{array}$ & This paper \\
\hline \multirow[t]{4}{*}{$\begin{array}{l}\text { B. Expertise and } \\
\text { investment related } \\
\text { barriers }\left(\mathrm{DAB}_{2}\right)\end{array}$} & $\begin{array}{l}\text { 1. Lack of skilled IT personnel } \\
\left(\mathrm{DAB}_{21}\right)\end{array}$ & $\begin{array}{l}\text { Lack of skilled IT personnel may increase } \\
\text { data input errors, data loss or confound } \\
\text { data analysis and interpretation. }\end{array}$ & $\begin{array}{l}\text { (Alharthi et al., } \\
\text { 2017; Malaka \& } \\
\text { Brown, 2015) }\end{array}$ \\
\hline & $\begin{array}{l}\text { 1. High cost of investment } \\
\left(\mathrm{DAB}_{22}\right)\end{array}$ & $\begin{array}{l}\text { The development of BDA tools for } \\
\text { particular organisations may require } \\
\text { substantial investment in data recording } \\
\text { and storage. }\end{array}$ & $\begin{array}{l}\text { (Malaka \& Brown, } \\
\text { 2015b) }\end{array}$ \\
\hline & 2. Lack of funding $\left(\mathrm{DAB}_{23}\right)$ & $\begin{array}{l}\text { Lack of funding to facilitate new software } \\
\text { and hardware development for BDA. }\end{array}$ & This paper \\
\hline & $\begin{array}{l}\text { 3. Lack of facilities to research } \\
\text { and develop BDA tools } \\
\left(\mathrm{DAB}_{24}\right)\end{array}$ & $\begin{array}{l}\text { Lack of interest in collaborating with } \\
\text { educational institutions to research existing } \\
\text { problems and develop BDA tools. }\end{array}$ & This paper \\
\hline \multirow[t]{4}{*}{$\begin{array}{l}\text { C. Data-related } \\
\text { barriers }\left(\mathrm{DAB}_{3}\right)\end{array}$} & $\begin{array}{l}\text { Complexity of data } \\
\text { integration }\left(\mathrm{DAB}_{31}\right)\end{array}$ & $\begin{array}{l}\text { Variety of data from different sources may } \\
\text { create complexity in data integration. }\end{array}$ & $\begin{array}{l}\text { (Alharthi et al., } \\
\text { 2017; Malaka \& } \\
\text { Brown, 2015; } \\
\text { Fallik, 2014) }\end{array}$ \\
\hline & 2. Data quality $\left(\mathrm{DAB}_{32}\right)$ & $\begin{array}{l}\text { Data quality varies due types of data } \\
\text { sources, storage media, companies and so } \\
\text { on. }\end{array}$ & $\begin{array}{l}\text { (Alharthi et al., } \\
\text { 2017; Malaka \& } \\
\text { Brown, 2015) }\end{array}$ \\
\hline & $\begin{array}{l}\text { 3. Data security and privacy } \\
\left(\mathrm{DAB}_{33}\right)\end{array}$ & $\begin{array}{l}\text { Data security and privacy are one of the } \\
\text { significant barriers to manufacturing } \\
\text { companies, as data must be secure if they } \\
\text { are to compete in the global market. }\end{array}$ & $\begin{array}{l}\text { (Alharthi et al., } \\
\text { 2017; Malaka \& } \\
\text { Brown, 2015) }\end{array}$ \\
\hline & $\begin{array}{l}\text { 4. Performance and scalability } \\
\left(\mathrm{DAB}_{34}\right)\end{array}$ & $\begin{array}{l}\text { Big data analytics requires massive } \\
\text { performance and scalability, which is one } \\
\text { of the most crucial challenges in using } \\
\text { BDA tools. }\end{array}$ & $\begin{array}{l}\text { (Malaka \& Brown, } \\
\text { 2015b) }\end{array}$ \\
\hline \multirow[t]{4}{*}{$\begin{array}{l}\text { D. Organizational } \\
\text { barriers }\left(\mathrm{DAB}_{4}\right)\end{array}$} & $\begin{array}{l}\text { 1. No policy to share data } \\
\text { among organisations } \\
\left(\mathrm{DAB}_{41}\right)\end{array}$ & $\begin{array}{l}\text { Lack of data sharing policies among } \\
\text { organisations. }\end{array}$ & This paper \\
\hline & $\begin{array}{l}\text { 2. Lack of training facilities } \\
\left(\mathrm{DAB}_{42}\right)\end{array}$ & $\begin{array}{l}\text { Adaptation of BDA inside manufacturing } \\
\text { companies may perhaps be obstructed by } \\
\text { the absence of suitable training facilities } \\
\text { for employees. }\end{array}$ & $\begin{array}{l}\text { (Malaka \& Brown, } \\
\text { 2015b) }\end{array}$ \\
\hline & 3. Time constraints $\left(\mathrm{DAB}_{43}\right)$ & $\begin{array}{l}\text { Time constraints are one of the biggest } \\
\text { issues in handling new projects in } \\
\text { manufacturing industries }\end{array}$ & $\begin{array}{l}\text { (Zhong et al., 2016; } \\
\text { Malaka \& Brown, } \\
\text { 2015) }\end{array}$ \\
\hline & $\begin{array}{l}\text { 4. Mindset in terms of big data } \\
\left(\mathrm{DAB}_{44}\right)\end{array}$ & $\begin{array}{l}\text { Stakeholders may be hesitant to use BDA } \\
\text { tools as this may require large investment } \\
\text { and extra unknown effort }\end{array}$ & This paper \\
\hline
\end{tabular}


Table 2: Summary of existing literature on big data

\begin{tabular}{|c|c|c|}
\hline Authors & Contributions & Methodology \\
\hline $\begin{array}{l}\text { Rousseaux } \\
(2017)\end{array}$ & $\begin{array}{l}\text { Used BD and data-driven intelligent predictive algorithms to assist } \\
\text { creativity in knowledge collection making }\end{array}$ & $\begin{array}{l}\text { Intelligent } \\
\text { predictive } \\
\text { algorithms }\end{array}$ \\
\hline $\begin{array}{l}\text { Alharthi et al. } \\
\text { (2017) }\end{array}$ & Analysed the use of BDA & $\begin{array}{l}\text { Conceptual } \\
\text { analysis }\end{array}$ \\
\hline $\begin{array}{l}\text { Ahmed et al. } \\
\text { (2017) }\end{array}$ & $\begin{array}{l}\text { Explored recent advances in BDA for IoT systems as well as the key } \\
\text { requirements for managing big data and enabling analytics in an IoT } \\
\text { environment }\end{array}$ & $\begin{array}{l}\text { Conceptual } \\
\text { analysis }\end{array}$ \\
\hline $\begin{array}{l}\text { Zhong et al. } \\
\text { (2016) }\end{array}$ & $\begin{array}{l}\text { Investigated representative BD applications from typical services } \\
\text { like finance \& economics, healthcare, supply chain management } \\
\text { (SCM) and the manufacturing sector }\end{array}$ & $\begin{array}{l}\text { Conceptual } \\
\text { analysis }\end{array}$ \\
\hline $\begin{array}{l}\text { Malaka and } \\
\text { Brown, (2015a) }\end{array}$ & $\begin{array}{l}\text { Investigated the challenges of BDA for the South African } \\
\text { telecommunications industry }\end{array}$ & $\begin{array}{l}\text { Conceptual } \\
\text { analysis }\end{array}$ \\
\hline $\begin{array}{l}\text { Addo-Tenkorang } \\
\text { and Helo (2016) }\end{array}$ & $\begin{array}{l}\text { Investigated BD and its application in operations or supply-chain } \\
\text { management }\end{array}$ & $\begin{array}{l}\text { Comprehensive } \\
\text { literature } \\
\text { review }\end{array}$ \\
\hline $\begin{array}{l}\text { Wang et al. } \\
(2017)\end{array}$ & $\begin{array}{l}\text { An integrated BDA-enabled transformation model: application to } \\
\text { healthcare }\end{array}$ & $\begin{array}{l}\text { Statistical } \\
\text { transformation } \\
\text { model }\end{array}$ \\
\hline $\begin{array}{l}\text { Sivarajah et al. } \\
\text { (2017) }\end{array}$ & Critical analysis of BD challenges and analytical methods & $\begin{array}{l}\text { A state-of-the- } \\
\text { art review }\end{array}$ \\
\hline Lee (2017) & $\begin{array}{l}\text { Illustrated the application of data analytics using merchant review } \\
\text { data }\end{array}$ & $\begin{array}{l}\text { Conceptual } \\
\text { analysis }\end{array}$ \\
\hline $\begin{array}{l}\text { Arunachalam et } \\
\text { al. (2017) }\end{array}$ & Examined the capabilities of BDA in the context of supply chains & $\begin{array}{l}\text { Systematic } \\
\text { literature } \\
\text { review }\end{array}$ \\
\hline
\end{tabular}

\subsection{AHP}

The AHP method, developed by Saaty, is usually employed to rank a number of selected factors or alternatives. It is used to evaluate multi-criteria decision analysis (MCDA) problems. The AHP tool helps to manage difficult decision-making processes and simplify the decision evaluation process. It is a famous decision making tool for multi criteria analysis due to it having wide acceptability and applicability, using fewer pairwise comparisons, and being easy to use (Paleie \& Lalic, 2009; Saaty, 2008; Shahin \& Mahbod, 2007). In AHP methodology, complex 
decision problems can be converted into hierarchical structures composed of different levels such as the goal of the research work, and major criteria and sub-criteria of the decision-making process (Sarmiento \& Thomas, 2010). The AHP method can support decision makers in the quantification of barriers.

However, AHP is very famous MCDA tool, but it sometimes gives unbalanced results due to unbalanced scale of judgments. To avoid this problem, several researchers offer extension of AHP method. As for example, Ilbahar et al., (2018) proposed Pythagorean fuzzy AHP \& fuzzy inference system to assess risk for occupational health and safety, Kokangül et al., (2017) utilized AHP and AHP and Fine Kinney methodologies to assess risk, Gottfried et al., (2018) applied an SWOT-AHP-TOWS analysis for chines biogas sector for private investment behavior analysis, Sennaroglu and Varlik Celebi, (2018) applied AHP integrated PROMETHEE and VIKOR methods to select a military airport location, Sirisawat and Kiatcharoenpol, (2018) proposed fuzzy based AHP-TOPSIS to prioritizing solution of reverse logistics barriers, Pamučar et al., (2018) utilized interval rough AHP and interval rough MABAC methods for evaluating university web pages. In this research, the AHP tool is used to examine and rank the barriers to using BDA in manufacturing supply chains. The authors of this article recommended that future researchers investigate barriers to BDA and compare our findings.

\section{Solution methodology}

\subsection{Delphi method}

The Delphi technique is a rational research method in which data are collected from a group of evaluators though a serious of structured questionnaires. It is a very dynamic method for assessing data in which experts/evaluators share their practical experiences to reach a convergence of opinions (Gordon, 2009; Hsu \& Sandford, 2007; Pawlowski \& Okoli, 2004). In current work, this methodological technique is used in assessing multi-criteria decision problems though a carefully designed questionnaire. In this study, the Delphi technique is employed to confirm the most relevant barriers to using BDA in manufacturing supply chains in the context 
of Bangladesh. To obtain superior and relevant outcomes for this research, we have considered responses from several operational and technical experts from different manufacturing industries.

To examine data in a Delphi study, there is no definite rule for selecting the maximum number of experts which can be included. Moreover, different rules have been used in the past to select experts for evaluation. In general, researchers have suggested that at least ten experts is sufficient to get reliable results. Okoli and Pawlowski (2004) advised that 10 to 18 experts' opinions should be considered to obtain a reliable mutual consensus. Murry and Hammons (1995) suggested that the feedback of 10 to 30 experts is necessary to obtain a reliable result. In this study, a total of 15 industrial managers were used. The experts assigned had sufficient knowledge and practical experience in operations management, IT and planning. A four-round Delphi technique was conducted to identify the most prominent barriers to using BDA in manufacturing supply chains. The proposed research framework is shown in Fig. 1. 


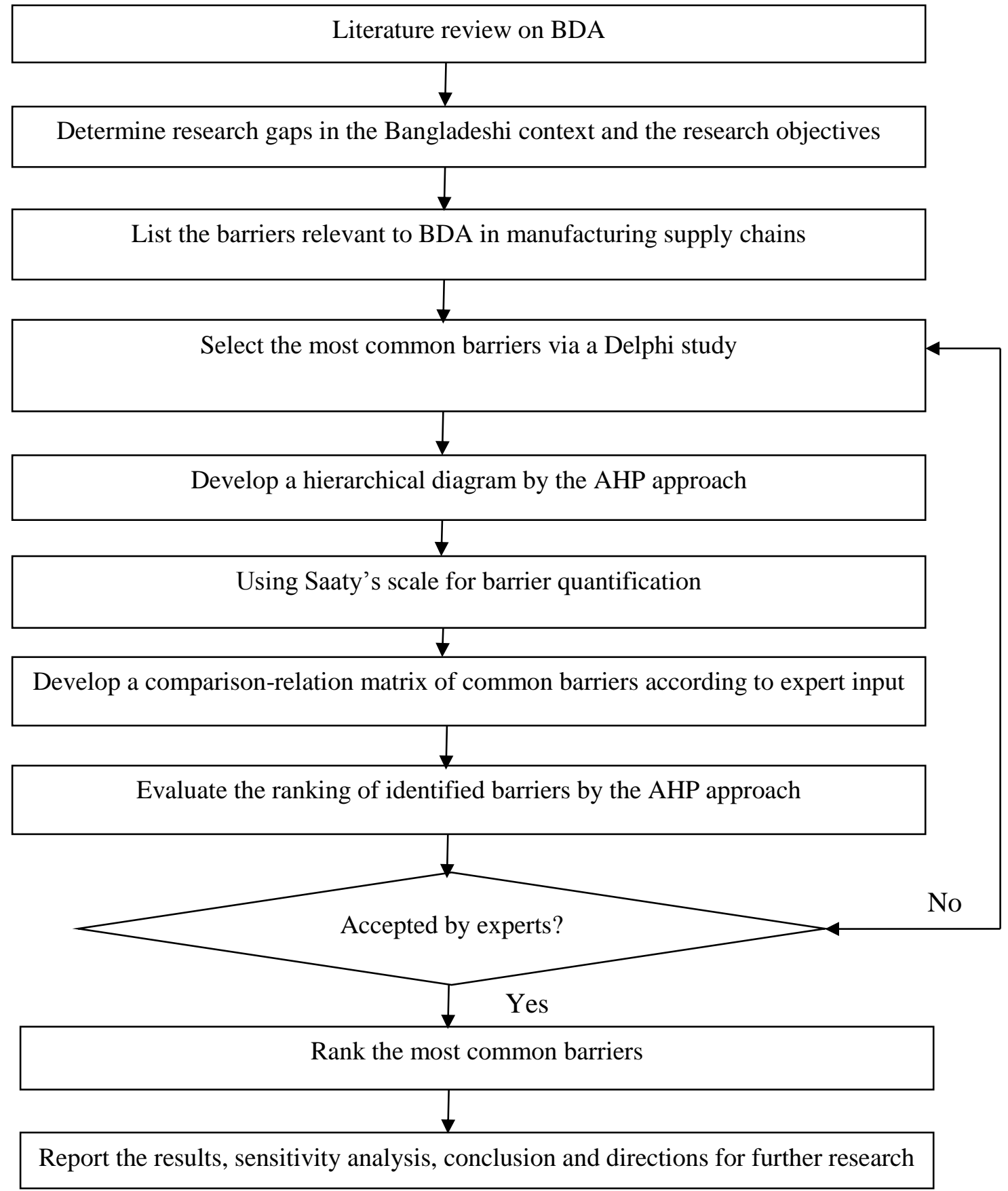

Fig.1. Flow diagram for the present research 


\subsection{AHP methodology}

The steps involved in the AHP method are presented below (An et al., 2017; Luthra et al., 2017b; Schoenherr et al., 2008):

Step 1: Define the objective of present research: We define our objective as examining the barriers to using BDA in manufacturing supply chains in Bangladesh.

Step 2: Build a pairwise comparisons matrix: In this step, with the assistance of expert input, a pairwise comparison relation matrix $(A)$ of identified barriers and sub-barriers is developed using Saaty's scale. In the matrix $A$, the element $a_{i j}$ denotes the relative importance of the $i^{\text {th }}$ BDA barrier with respect to the $j^{\text {th }}$ BDA barrier. The notation is presented as follows: $A=\left[a_{i j}\right]$. Each entry in matrix $A$ is positive $\left(a_{i j}>0\right.$; (Jaberidoost et al., 2015). If the identified barrier is $m$, the pairwise relation matrix can be shown as follows:

$$
A=\left(\begin{array}{cccc}
1 & a_{12} & \ldots & a_{1 m} \\
a_{21} & 1 & \ldots & a_{2 m} \\
\ldots & \ldots & \ldots & \ldots \\
a_{m 1} & a_{m 2} & \ldots & 1
\end{array}\right)
$$

Where $a_{i j}$ indicates the relative importance of barrier $i$ compared with barrier $j$. The relative importance of barrier $j$ compared with barrier $i$ can be calculated as follows:

$$
a_{j i}=\frac{1}{a_{i j}} ; a_{i j}>0 i, j=1,2,3, \ldots, m
$$

Step 3: Calculate the priority weights: In this step, the developed pairwise comparison matrices of barriers and sub-barriers are then used to calculate the eigenvalues and eigenvector. Next, the weights of the barriers are calculated with the help of following equation. 


$$
\left(\begin{array}{cccc}
1 & a_{12} & \ldots & a_{1 m} \\
a_{21} & 1 & \ldots & a_{2 m} \\
\ldots & \ldots & \ldots & \ldots \\
a_{m 1} & a_{m 2} & \ldots & 1
\end{array}\right) \times\left(\begin{array}{c}
w_{1} \\
w_{2} \\
. . \\
w_{m}
\end{array}\right)=\lambda \max \left(\begin{array}{c}
w_{1} \\
w_{2} \\
. . \\
w_{m}
\end{array}\right)
$$

Where $\lambda$ max indicates the maximum eigenvalue of matrix $A$, which can be calculated from eigenvector $W_{\max }=\left[w_{1}, w_{2}, \ldots ., w_{m}\right]$

The normalised value of the barriers can be calculated by a normalisation process for the eigenvector, as shown below:

$W=\left(\frac{w_{1}}{\sum_{i=1}^{m} w_{i}}, \frac{w_{2}}{\sum_{i=1}^{m} w_{i}}, \ldots . ., \frac{w_{m}}{\sum_{i=1}^{m} w_{i}}\right)^{T}$

Where $W$ denotes the weight coefficient vector and $w_{i}$ represents the weights of barriers $i$. Here, $m$ denotes the total number of barriers.

Step 4: Investigation of the consistency ratio: Consistency of pairwise comparison matrices can be checked by using following equation:

$$
\mathrm{CR}=\mathrm{CI} / \mathrm{RI}
$$

Here, CR denotes the consistency ratio, CI denotes the consistency index, and RI denotes the random consistency index. The value of RI is given in Table 3. The value of CR should be less than 0.10 to achieve a better level of consistency (Madaan \& Mangla, 2015). Therefore, we can compute the CI values with the help of the equation:

$$
C I=\frac{\lambda_{\max }-n}{n-1}
$$


Table 3: Random consistency index values

\begin{tabular}{|c|c|c|c|c|c|c|c|c|c|c|}
\hline$n$ & 1 & 2 & 3 & 4 & 5 & 6 & 7 & 8 & 9 & 10 \\
\hline RI & 0 & 0 & 0.58 & 0.9 & 1.12 & 1.24 & 1.32 & 1.41 & 1.45 & 1.49 \\
\hline
\end{tabular}

\section{An exemplary application}

\subsection{Selection of companies and respondents}

Bangladesh is a developing country which has higher unemployment rate, lower level of business activity compared to the U.S. but has much higher economic growth rates. Recently, the demand of $\mathrm{BDA}$ tools for minimizing process flaws, production risks, and market losses has pushed manufacturing companies to adopt BDA tools. Several manufacturing companies are also trying to incorporate BDA tools for sustainable long term development (Kwon, Lee, \& Shin, 2014; Xu, Frankwick, \& Ramirez, 2016). Adopting BDA in manufacturing companies in Bangladesh is still in nascent stage of adaptation. Hence, BDA tools can help companies to implement sustainable manufacturing practices and risk management in supply chains.

Therefore, it is necessary to identify the barriers to BDA. In this research, we used a purposive sampling method whereby the case-in-point company is not selected randomly (Bai et al., 2017; Maalouf \& Gammelgaard, 2016). In this case, we investigated five large-scale manufacturing companies. The five large-scale manufacturing companies were selected due to their intense interest to assess the nature of BDA barriers. Accordingly, fifteen industrial managers from the companies were selected for data collection and result validation based on purposive sampling technique due to they are knowledgeable on the subject matter.

In brief, a two-phased approach was used to analyse data. Phase 1 identified the most relevant barriers with the help of industrial experts within a Delphi study, while Phase 2 ranked the barriers with the help of AHP. A group of 15 experts was asked to express their feedback in selecting the potential barriers to BDA from a list identified from the literature review by assigning "0" (negative) and "1" (affirmative). The profiles of case companies and respondents are tabulated in Table 4. The hierarchical structure of barriers to BDA in manufacturing supply chains is presented in Fig. 2. 
Table 4: Profiles of case companies and respondents

\begin{tabular}{|c|c|c|c|c|}
\hline Name of company & $\begin{array}{l}\text { Types of } \\
\text { products }\end{array}$ & Respondent & $\begin{array}{l}\text { Years of } \\
\text { experience }\end{array}$ & $\begin{array}{l}\text { Company size (area, employees, } \\
\text { annual sales turnover for FY-2016) }\end{array}$ \\
\hline \multirow{3}{*}{$\begin{array}{l}\text { 'A' Leather } \\
\text { manufacturing } \\
\text { company }\end{array}$} & \multirow{3}{*}{$\begin{array}{l}\text { Crust leather, } \\
\text { chrome tanned } \\
\text { leather, finished } \\
\text { leather. }\end{array}$} & $\begin{array}{l}\text { Supply chain } \\
\text { manager }\end{array}$ & 13 years & \multirow{3}{*}{$\begin{array}{l}\text { Area: } 1.5 \text { acres } \\
\text { Employees: } 120 \\
\text { Annual sales turnover: USD } \$ 40 \\
\text { million. }\end{array}$} \\
\hline & & Logistics manager & 14 years & \\
\hline & & Technologist & 10 years & \\
\hline \multirow[t]{3}{*}{$\begin{array}{l}\text { 'B' Footwear } \\
\text { manufacturing } \\
\text { company }\end{array}$} & \multirow{3}{*}{$\begin{array}{l}\text { Oxford shoes, } \\
\text { derby shoes, } \\
\text { court shoes, } \\
\text { casual shoes, } \\
\text { etc. }\end{array}$} & $\begin{array}{l}\text { Operations } \\
\text { manager }\end{array}$ & 16 years & \multirow{3}{*}{$\begin{array}{l}\text { Area: } 3.42 \text { acres } \\
\text { Employees: } 5500 \\
\text { Annual sales turnover: USD } \$ 1.1 \\
\text { billion }\end{array}$} \\
\hline & & Shoe designer & 12 years & \\
\hline & & IT specialist & 7 years & \\
\hline \multirow[t]{3}{*}{$\begin{array}{l}\text { 'C' Leather products } \\
\text { manufacturing } \\
\text { company }\end{array}$} & \multirow{3}{*}{$\begin{array}{l}\text { Gents wallets, } \\
\text { ladies bags, } \\
\text { travel bags, } \\
\text { executive bags, } \\
\text { etc. }\end{array}$} & Logistics manager & 13 years & \multirow{3}{*}{$\begin{array}{l}\text { Area: } 2.15 \text { acres } \\
\text { Employees: } 1400 \\
\text { Annual sales turnover: USD } \$ 56 \\
\text { million }\end{array}$} \\
\hline & & $\begin{array}{l}\text { Production } \\
\text { manager }\end{array}$ & 14 years & \\
\hline & & $\begin{array}{l}\text { Supply chain } \\
\text { executive }\end{array}$ & 12 years & \\
\hline \multirow{3}{*}{$\begin{array}{l}\text { 'D' Leather garments } \\
\text { manufacturing } \\
\text { company }\end{array}$} & \multirow{3}{*}{$\begin{array}{l}\text { Leather jackets, } \\
\text { waistcoats, } \\
\text { skirts, etc. }\end{array}$} & R \& D manager & 16 years & \multirow{3}{*}{$\begin{array}{l}\text { Area: } 0.45 \text { acre } \\
\text { Employees: } 215 \\
\text { Annual sales turnover: USD } \$ 21 \\
\text { million }\end{array}$} \\
\hline & & Designer & 8 years & \\
\hline & & Operations manger & 10 years & \\
\hline \multirow[t]{3}{*}{$\begin{array}{l}\text { 'E' Synthetic } \\
\text { processing company }\end{array}$} & \multirow{3}{*}{$\begin{array}{l}\text { PVC \& PU } \\
\text { sheet materials, } \\
\text { rubber soles, } \\
\text { insoles, } \\
\text { outsoles, etc. }\end{array}$} & Technologist & 9 years & \multirow{3}{*}{$\begin{array}{l}\text { Area: } 1.29 \text { acres } \\
\text { Employees: } 120 \\
\text { Annual sales turnover: USD } \$ 32 \\
\text { million }\end{array}$} \\
\hline & & $\begin{array}{l}\text { Supply chain } \\
\text { manger }\end{array}$ & 13 years & \\
\hline & & Logistics manager & 10 years & \\
\hline
\end{tabular}




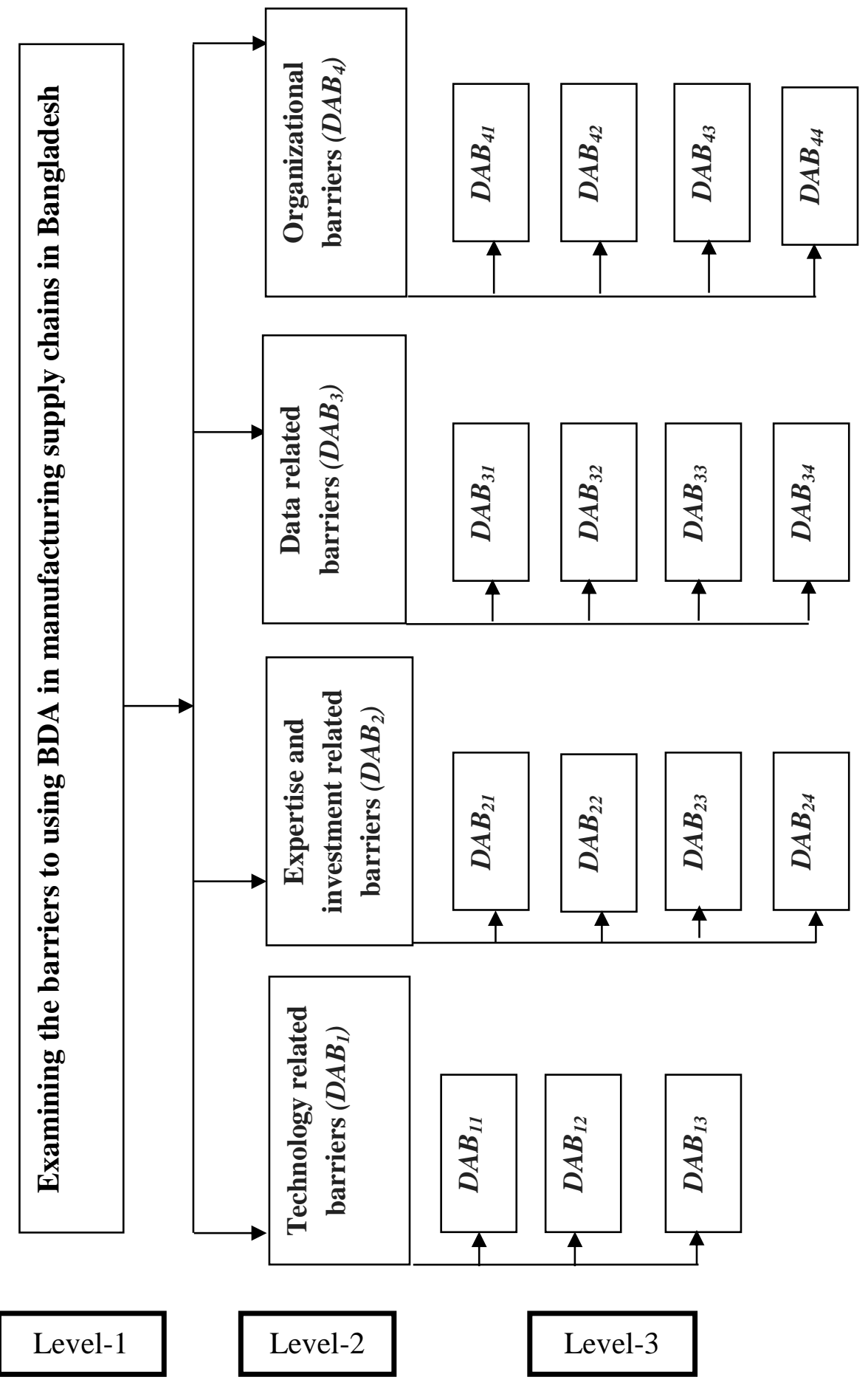

Fig. 2: Hierarchical structure of barriers to BDA in manufacturing supply chains 


\subsection{Application of Delphi-based AHP}

Phase 1: Identify the most significant barriers to using BDA in manufacturing supply chains

In this phase, we selected the most important barriers to using BDA in manufacturing supply chains following a design procedure (see Section 2.3). A list of barriers for analysing rankings was fixed and is shown in Table 1.

\section{Phase 2: Evaluating barriers to using BDA in manufacturing supply chains}

In this phase, the finalised barriers were prioritised with the AHP tool and the assistance of assigned respondents' feedback. After this, a hierarchical decision framework was established using experts' feedback. This hierarchical structure is comprised of three levels: examining the barriers to using BDA in manufacturing supply chains in the context of Bangladesh (Level-1), four main barriers (Level-2) and fifteen sub-barriers (Level-3).

With the assistance of experts' opinions, the pairwise comparison matrix was formed among major barriers and sub-barriers using Saaty's scale. First, we constructed a pairwise comparison matrix of major barriers using Equations (1) and (2), then we constructed a pairwise comparison matrix of the sub-barriers. After that, we calculated the rankings using Equations (3), (4), (5), (6), and (7). The pairwise comparison matrix of major barriers is presented in Table 5. The pairwise comparison matrix of sub-barriers was constructed in a similar way.

Table 5: Pairwise assessment matrix for major categories of barriers

\begin{tabular}{|c|c|c|c|c|c|c|}
\hline Major barrier & $\mathrm{DAB}_{1}$ & $\mathrm{DAB}_{2}$ & $\mathrm{DAB}_{3}$ & $\mathrm{DAB}_{4}$ & Relative weight & Rank \\
\hline $\mathrm{DAB}_{1}$ & 1 & 2 & 1 & 3 & 0.3359 & 2 \\
\hline $\mathrm{DAB}_{2}$ & 0.5 & 1 & $1 / 2$ & 3 & 0.1997 & 3 \\
\hline $\mathrm{DAB}_{3}$ & 1 & 2 & 1 & 5 & 0.3816 & 1 \\
\hline $\mathrm{DAB}_{4}$ & $1 / 3$ & $1 / 3$ & 0.2 & 1 & 0.0829 & 4 \\
\hline
\end{tabular}

$\lambda_{\max }=4.04118 ; \mathrm{CI}=0.01373 ; \mathrm{CR}=0.01525097<0.1$ 
Table 6: Pairwise assessment matrix for 'Technology-related barriers (DAB1)' to using BDA in manufacturing supply chains

\begin{tabular}{|c|c|c|c|c|c|}
\hline $\mathrm{DAB}_{1}$ & $\mathrm{DAB}_{11}$ & $\mathrm{DAB}_{12}$ & $\mathrm{DAB}_{13}$ & Relative weight & Rank \\
\hline $\mathrm{DAB}_{11}$ & 1 & $1 / 2$ & 3 & 0.3090 & 2 \\
\hline $\mathrm{DAB}_{12}$ & 2 & 1 & 5 & 0.5816 & 1 \\
\hline $\mathrm{DAB}_{13}$ & $1 / 3$ & $1 / 5$ & 1 & 0.1095 & 3 \\
\hline
\end{tabular}

$\lambda_{\max }=3.00369 ; \mathrm{CI}=0.00185 ; \mathrm{CR}=0.00318<0.1$

Similarly, relative weights of other sub-barriers are computed as given in Appendix-1 in Tables A1-A3.

Finally, the global weight of each barrier was calculated by multiplying the relative weights of the major barriers with the relative weights of the sub-barriers. Therefore, ranking of subbarriers was determined according to the global weights of each barrier (see Table 7). The global rankings of selected barriers is presented in Table 7, which shows that data-related barriers $\left(\mathrm{DAB}_{3}\right)$ have the highest weights. This means that data-related barriers $\left(\mathrm{DAB}_{3}\right)$ are the major obstacles to the adoption of BDA in Bangladeshi manufacturing industries. Consequently, other barriers, such as technology-related barriers $\left(\mathrm{DAB}_{1}\right)$, organisational barriers $\left(\mathrm{DAB}_{2}\right)$, and expertise- and investment-related barriers $\left(\mathrm{DAB}_{4}\right)$ were ranked second, third and fourth. These three barriers also act as a set of challenges in using BDA. The sub-barrier 'lack of infrastructural facility $\left(\mathrm{DAB}_{12}\right)^{\prime}$ 'was ranked first. This indicates that decision makers should pay greater attention to this barrier when adopting BDA in manufacturing supply chains.

\section{Results and discussion}

In this section, we discuss the details of our research findings. These findings may help decision makers to understand the barriers to $\mathrm{BDA}$ in manufacturing supply chains in Bangladesh. The findings reveal that the ranking of specific sub-barriers can be summarised as follows: $\mathrm{DAB}_{12}>\mathrm{DAB}_{31}>\mathrm{DAB}_{33}>\mathrm{DAB}_{11}>\mathrm{DAB}_{22}>\mathrm{BAD}_{32}>\mathrm{DAB}_{21}>\mathrm{DAB}_{23}>\mathrm{DAB}_{43}>$ $\mathrm{DAB}_{13}>\mathrm{DAB}_{34}>\mathrm{DAB}_{41}>\mathrm{DAB}_{24}>\mathrm{DAB}_{42}>\mathrm{DAB}_{44}$. Note that lack of infrastructural facility $\left(\mathrm{DAB}_{12}\right)$ was ranked highest, indicating that this is the greatest sub-barrier to using BDA in Bangladeshi manufacturing industries. In addition, 'mindset in terms of big data (DAB $\left.{ }_{44}\right)$ ' was ranked lowest. This sub-barrier may also be an issue in the adoption of BDA, as in the Bangladeshi context, manufacturers are unwilling to adopt BDA due to the extra investment required and the long times needed to analyse $\mathrm{BD}$. 
Table 7: Global ranking of barriers to using BDA in manufacturing supply chains

\begin{tabular}{|c|c|c|c|c|c|c|}
\hline $\begin{array}{l}\text { Major } \\
\text { barrier }\end{array}$ & $\begin{array}{c}\text { Relative } \\
\text { weight }\end{array}$ & Sub-barrier & $\begin{array}{l}\text { Relative } \\
\text { weights }\end{array}$ & $\begin{array}{l}\text { Relative } \\
\text { rank }\end{array}$ & $\begin{array}{c}\text { Global } \\
\text { weights }\end{array}$ & $\begin{array}{c}\text { Global } \\
\text { rank }\end{array}$ \\
\hline \multirow{3}{*}{$\begin{array}{l}\text { Technology } \\
\text { related barriers } \\
\left(\mathrm{DAB}_{1}\right)\end{array}$} & \multirow{3}{*}{0.3358} & Lack of availability of BDA tools $\left(\mathrm{DAB}_{11}\right)$ & 0.3090 & 2 & 0.1038 & 4 \\
\hline & & Lack of infrastructural facility $\left(\mathrm{DAB}_{12}\right)$ & 0.5816 & 1 & 0.1953 & 1 \\
\hline & & $\begin{array}{l}\text { Lack of interest to hire high technology } \\
\left(\mathrm{DAB}_{13}\right)\end{array}$ & 0.1095 & 3 & 0.0368 & 10 \\
\hline \multirow{4}{*}{$\begin{array}{l}\text { Expertise and } \\
\text { investment } \\
\text { related barriers } \\
\left(\mathrm{DAB}_{2}\right)\end{array}$} & \multirow{4}{*}{0.1997} & Lack of skilled IT personnel $\left(\mathrm{DAB}_{21}\right)$ & 0.2818 & 2 & 0.0563 & 7 \\
\hline & & High cost of investment $\left(\mathrm{DAB}_{22}\right)$ & 0.4214 & 1 & 0.0842 & 5 \\
\hline & & Lack of funding $\left(\mathrm{DAB}_{23}\right)$ & 0.2141 & 3 & 0.0428 & 8 \\
\hline & & $\begin{array}{l}\text { Lack of facility on research to develop } \\
\text { BDA tool }\left(\mathrm{DAB}_{24}\right)\end{array}$ & 0.0827 & 4 & 0.0165 & 13 \\
\hline \multirow{4}{*}{$\begin{array}{l}\text { Data related } \\
\text { barriers }\left(\mathrm{DAB}_{3}\right)\end{array}$} & \multirow{4}{*}{0.3816} & Complexity of data integration $\left(\mathrm{DAB}_{31}\right)$ & 0.3856 & 1 & 0.1472 & 2 \\
\hline & & Data quality $\left(\mathrm{DAB}_{32}\right)$ & 0.1823 & 3 & 0.0696 & 6 \\
\hline & & Data privacy $\left(\mathrm{DAB}_{33}\right)$ & 0.3394 & 2 & 0.1295 & 3 \\
\hline & & Performance and scalability $\left(\mathrm{DAB}_{34}\right)$ & 0.0927 & 4 & 0.0354 & 11 \\
\hline \multirow{4}{*}{$\begin{array}{l}\text { Organisational } \\
\text { barriers }\left(\mathrm{DAB}_{4}\right)\end{array}$} & \multirow{4}{*}{0.0829} & $\begin{array}{l}\text { No policy to share data among } \\
\text { organisations }\left(\mathrm{DAB}_{41}\right)\end{array}$ & 0.2913 & 2 & 0.0241 & 12 \\
\hline & & Lack of training facilities $\left(\mathrm{DAB}_{42}\right)$ & 0.1727 & 3 & 0.0143 & 14 \\
\hline & & Time constraints $\left(\mathrm{DAB}_{43}\right)$ & 0.4681 & 1 & 0.0388 & 9 \\
\hline & & Mindset in terms of big data $\left(\mathrm{DAB}_{44}\right)$ & 0.0680 & 4 & 0.0056 & 15 \\
\hline
\end{tabular}

\subsection{Technology-related barriers $\left(D A B_{1}\right)$}

Technology-related barriers (DAB1) are ranked second amongst the four major barriers, which is an indication of their significance. In the context of manufacturing industries, technology-related barriers are currently a major obstacle. Studies conducted by different authors have shown that a lack of technology is the main barrier to managing big data in manufacturing supply chains (Alharthi et al., 2017; Malaka \& Brown, 2015a). Alharthi et al. (2017) examined this barrier and showed that technologies capable of handling BD are not currently available. Another study by Malaka and Brown (2015a) showed that technological improvement is necessary to manage BD. Managing BD is the main challenge for today's businesses. 
We have examined some of the technology-related barriers to better understand them. In this category of barriers, lack of infrastructural facility $\left(\mathrm{DAB}_{12}\right)$ is the highest-ranked sub-barrier. So, manufacturing industries should prioritise attention on this barrier. Industrial managers should take action to improve the infrastructure that can manage BD. Without technological infrastructure development, manufacturing companies may not adopt BDA tools. The lack of availability of $B D A$ tools $\left(\mathrm{DAB}_{11}\right)$ in manufacturing industries is another barrier to using BDA. The demand for BDA tools in manufacturing supply chains is considerable. This sub-barrier takes second position in the ranking. Therefore, industrial managers should see this as a major challenge and give it proper attention (Chen \& Zhang, 2014). To manage BD, it is important to develop BDA tools; these tools may work as drivers to improve business performance. The lack of interest in implementing advanced technology $\left(\mathrm{DAB}_{13}\right)$ was next in the sub-barrier ranking. Manufacturing industries are not interested in purchasing high technology to manage BD as it requires a large investment. Newly-established manufacturing companies should allocate more of their budget to the acquisition of technology; as such technology can improve business performance.

\subsection{Expertise- and investment-related barriers $\left(\mathrm{DAB}_{2}\right)$}

In this research, expertise- and investment-related barriers $\left(\mathrm{DAB}_{2}\right)$ was ranked third of the four major barriers. It is necessary to realise the sources of these barriers and the related hurdles of using BDA in manufacturing supply chains. The sub-barriers: lack of skilled IT personnel $\left(\mathrm{DAB}_{21}\right)$, high cost of investment $\left(\mathrm{DAB}_{22}\right)$, lack of funding $\left(\mathrm{DAB}_{23}\right)$, and lack of research facilities to develop BDA tools $\left(\mathrm{DAB}_{24}\right)$ all contribute significantly to the adoption of BDA. High cost of investment $\left(\mathrm{DAB}_{22}\right)$ was ranked first in this category. It means that cost is a big hurdle in adopting BDA. Manufacturers always try to minimise the costs of their products, which is why they do not want to adopt BDA. It is a key barrier in the manufacturing industries of Bangladesh. From the previous studies, no specific rankings were made to investigate data-related barriers to using BDA (Alharthi et al., 2017; Malaka \& Brown, 2015a; Sivarajah et al., 2017). In this study, we ranked the sub-barriers to better understand them. Moreover, this study helps industrial managers to formulate some strategic decisions regarding the implementation of BDA in supply chains. Next, lack of skilled IT personnel $\left(\mathrm{DAB}_{21}\right)$ was in second position. Manufacturers always face difficulties in handling BDA due to a lack of expert IT personnel. This may act as the key 
barrier in the current scenario. Lack of funding $\left(\mathrm{DAB}_{23}\right)$ holds third position. This confirms that funding is not available from manufacturers. Hence, it is more important to facilitate the funding of BDA. This research confirms that the lack of funding is not a negligible influence. Therefore, manufacturers should provide more funding. Finally, lack of facility on research to develop BDA tool $\left(\mathrm{DAB}_{24}\right)$ was in the last position in this category of major barriers. This indicates that industrial managers should develop specialised departments to build new BDA tools for particular products and activities as required. This is not an easy task due to the funding required for this area. Hence, it may be beneficial in improving business performance and product quality. Long-term economic benefits can be achieved by developing specialised research departments.

\subsection{Data-related barriers $\left(D A B_{3}\right)$}

Manufacturing companies may face hurdles in handling data due to the complexity of data integration $\left(\mathrm{DAB}_{31}\right)$, data quality $\left(\mathrm{DAB}_{32}\right)$, data privacy $\left(\mathrm{DAB}_{33}\right)$, and performance and scalability $\left(\mathrm{DAB}_{34}\right)$. In this research, complexity of data integration $\left(\mathrm{DAB}_{31}\right)$ was ranked first. Due to complexity of data integration, most manufacturers are unwilling to use BDA. This is an important hurdle for manufacturing industries. Therefore, in this research, it was assigned the highest priority. Data integration can be achieved more smoothly by developing specialised BDA tools. This result suggests that manufacturers should give greater attention to handling this issue by facilitating greater funding and conducting more research on it. Next, data privacy $\left(\mathrm{DAB}_{33}\right)$ was ranked second, in contrast to Alharthi et al. (2017), who did not rank this barrier. Most manufacturers do not want to share their data through the internet. It is a large task to analyse the actual nature of data. Hence, this barrier should be minimised by formulating cooperative policies between manufacturers, between suppliers, between manufacturers and buyers, and between manufacturers and policy makers. Next was ranked data quality $\left(\mathrm{DAB}_{32}\right)$. Data quality is an important hurdle, as data varies between industries, products and markets. It is an important point that accumulating data for proper analysis is a complex task. Hence, manufacturers should develop quality tools to handle this barrier. Finally, performance and scalability $\left(\mathrm{DAB}_{34}\right)$ was ranked last. The performance and scalability of data is a big issue in the manufacturing industries. Therefore, proper consideration of data management is necessary for industrial managers. 


\subsection{Organisational barriers $\left(\mathrm{DAB}_{4}\right)$}

Of the four major barriers, organisational barriers $\left(\mathrm{DAB}_{4}\right)$ is ranked last. Within this major barrier are the four sub-barriers of no policy to share data among organisations $\left(\mathrm{DAB}_{41}\right)$, lack of training facilities $\left(\mathrm{DAB}_{42}\right)$, time constraints $\left(\mathrm{DAB}_{43}\right)$ and mindset in terms of big data $\left(\mathrm{DAB}_{44}\right)$. Time constraints $\left(\mathrm{DAB}_{43}\right)$ was ranked as the most important sub-barrier. Most manufacturers want to minimise production and delivery times, and all other times relevant to the manufacturing process. As such, time constraint is the biggest issue in the use of BDA. Large amounts of time are required to analyse big datasets due to the complexity of data integration, variety and privacy. It is important to analyse data to perform better in the global market. Therefore, industrial managers should allow reasonable amounts of time to analyse data to improve market performance. A study conducted by Malaka and Brown (2015a) has shown that time constraints are a big challenge for manufacturers, which is consistent with the current study. This study will help manufacturers and industrial managers to understand the barriers and their impacts, so they will be able to formulate the strategic policies necessary for adopting BDA in their manufacturing supply chains. Next, no policy to share data among organisations $\left(\mathrm{DAB}_{41}\right)$ ' received the second rank. This suggests that Bangladeshi manufacturing companies are hesitant to share data among companies within their supply chains. This is a big challenge to using BDA in manufacturing supply chains. The study conducted by Alharthi et al. (2017) confirmed that the presence of sharing policies is an important issue for business development as well as in the adoption of BDA tools. This finding will encourage decision makers to develop policies of cooperation among manufacturers. Manufacturing companies should give appropriate attention to their data sharing policies or mechanisms. Lack of training facilities $\left(\mathrm{DAB}_{42}\right)$ is ranked third in the category. Regular and appropriate training is key to the success of businesses worldwide. Industrial managers should facilitate training programs that consider BD and BDA tools. By facilitating training programs, IT personnel can acquire an appropriate level of knowledge and competency in using BDA tools. This can help manufacturing companies to perform better in the global market. This barrier can be mitigated by arranging regular and appropriate training programs. Finally, mindset in terms of big data $\left(\mathrm{DAB}_{44}\right)$ was ranked last in this category, although its effect is not negligible. Business success largely depends on the mindsets of decision makers, and industrial managers must understand the benefits of adopting $\mathrm{BD}$ in the long term. 


\section{Sensitivity analysis}

In MCDA analyses, the results may be affected by data vagueness and inaccuracy, and experts' judgments. Also, small changes in relative weights may lead to alternate ranking profiles (Govindan et al., 2014; Mangla et al., 2017). Govindan et al. (2014) investigated rankings by sensitivity analysis and showed that small variations in weights may change the final ranking. Therefore, it is important to analyse the robustness of the ranking obtained. We did this by performing a sensitivity analysis to investigate the final ranking of our obtained results.

In this work, data-related barriers $\left(\mathrm{DAB}_{3}\right)$ was ranked the first of the four major barriers (see Table 7). Therefore, it was selected first for analysis by changing the barrier weightings. The weighting of data related-barriers $\left(\mathrm{DAB}_{3}\right)$ was varied from 0.1 to 0.9 in increments of 0.1 . Simultaneously, corresponding changes in the weights of the other major barriers were made. The sensitivity analysis shows that the maximum changes occurred for technology-related barriers $\left(\mathrm{DAB}_{1}\right.$; see Table 7$)$. The changes in the weights of the other barriers are shown in Table 8 .

Table 8: Values of preference weights for sensitivity analysis of the major barriers

\begin{tabular}{|l|r|c|c|c|c|c|c|c|c|c|}
\hline \multicolumn{1}{|l|}{ Major barrier } & \multicolumn{10}{|c|}{ Values of preference weights } \\
\hline & Normal $(0.3816)$ & 0.1 & 0.2 & 0.3 & 0.4 & 0.5 & 0.6 & 0.7 & 0.8 & 0.9 \\
\hline DAB $_{1}$ & 0.3358 & 0.4888 & 0.4345 & 0.3802 & 0.3258 & 0.2715 & 0.2172 & 0.1629 & 0.1086 & 0.0543 \\
\hline DAB $_{2}$ & 0.1997 & 0.2906 & 0.2583 & 0.2260 & 0.1938 & 0.1615 & 0.1292 & 0.0969 & 0.0646 & 0.0323 \\
\hline DAB $_{3}$ & 0.3816 & 0.1000 & 0.2000 & 0.3000 & 0.4000 & 0.5000 & 0.6000 & 0.7000 & 0.8000 & 0.9000 \\
\hline DAB $_{4}$ & 0.0829 & 0.1206 & 0.1072 & 0.0938 & 0.0804 & 0.0670 & 0.0536 & 0.0402 & 0.0268 & 0.0134 \\
\hline Total & 1.0000 & 1.0000 & 1.0000 & 1.0000 & 1.0000 & 1.0000 & 1.0000 & 1.0000 & 1.0000 & 1.0000 \\
\hline
\end{tabular}

It should be also noted that the weights and rankings of the sub-barriers will also change as the weights of the major barriers are varied. From Table 9, it is evident that when the weight of data-related barriers $\left(\mathrm{DAB}_{3}\right)$ is in the range $0.1-0.4$, the specific barrier lack of infrastructural facilities $\left(\mathrm{DAB}_{12}\right)$ gets top rank. However, mindset in terms of big data (DAB 44$)$ gets last rank when $\mathrm{DAB}_{3}$ weights are varied from 0.1 up to 0.9 . When varying data-related barriers $\left(\mathrm{DAB}_{3}\right)$ weights from 0.5 to 0.9 , the sub-barrier complexity of data integration $\left(\mathrm{DAB}_{31}\right)$ got the top rank whereas data privacy $\left(\mathrm{DAB}_{33}\right)$ is ranked second. At the same time, the rankings of all the other sub-barriers were also investigated. Global weights for the sub-barriers when the weight of data-related barriers $\left(\mathrm{DAB}_{3}\right)$ was varied from 0.1 to 0.9 are provided in Table 9 . 
Table 9: Global weights for sub-barriers according to sensitivity analysis when the weight of data-related barriers $\left(\mathrm{DAB}_{3}\right)$ is varied from 0.1 to 0.9 .

\begin{tabular}{|c|c|c|c|c|c|c|c|c|c|c|}
\hline Barrier & $\begin{array}{l}\text { Normal } \\
(\mathbf{0 . 3 8 1 6 )} \\
\end{array}$ & 0.1 & 0.2 & 0.3 & 0.4 & 0.5 & 0.6 & 0.7 & 0.8 & 0.9 \\
\hline DAB $_{11}$ & 0.10378 & 0.15103 & 0.13425 & 0.11747 & 0.10069 & 0.08391 & 0.06713 & 0.05034 & 0.03356 & 0.01678 \\
\hline $\mathrm{DAB}_{12}$ & 0.19531 & 0.28425 & 0.25267 & 0.22109 & 0.1895 & 0.15792 & 0.12634 & 0.09475 & 0.06317 & 0.03158 \\
\hline $\mathrm{DAB}_{13}$ & 0.03676 & 0.0535 & 0.04755 & 0.04161 & 0.03567 & 0.02972 & 0.02378 & 0.01783 & 0.01188 & 0.00595 \\
\hline DAB $_{21}$ & 0.05628 & 0.0819 & 0.0728 & 0.0637 & 0.0546 & 0.0455 & 0.0364 & 0.0273 & 0.0182 & 0.0091 \\
\hline $\mathbf{D A B}_{22}$ & 0.08415 & 0.12247 & 0.10886 & 0.09526 & 0.08165 & 0.06804 & 0.05443 & 0.04082 & 0.02722 & 0.01361 \\
\hline $\mathbf{D A B}_{23}$ & 0.04276 & 0.06223 & 0.05532 & 0.0484 & 0.04149 & 0.03457 & 0.02766 & 0.02074 & 0.01383 & 0.00691 \\
\hline DAB $_{24}$ & 0.01651 & 0.02403 & 0.02136 & 0.01869 & 0.01602 & 0.01335 & 0.01068 & 0.00801 & 0.00534 & 0.00267 \\
\hline DAB $_{31}$ & 0.14715 & 0.03856 & 0.07712 & 0.11568 & 0.15425 & 0.19281 & 0.23137 & 0.26994 & 0.30849 & 0.34705 \\
\hline DAB $_{32}$ & 0.06958 & 0.01823 & 0.03647 & 0.0547 & 0.07293 & 0.09117 & 0.10941 & 0.12764 & 0.14588 & 0.16411 \\
\hline $\mathbf{D A B}_{33}$ & 0.12951 & 0.03395 & 0.06789 & 0.10182 & 0.13575 & 0.16969 & 0.20363 & 0.23757 & 0.27151 & 0.30545 \\
\hline DAB $_{34}$ & 0.03536 & 0.00927 & 0.01853 & 0.0278 & 0.03706 & 0.04633 & 0.05559 & 0.06486 & 0.07412 & 0.08339 \\
\hline $\mathbf{D A B}_{41}$ & 0.02413 & 0.03512 & 0.03122 & 0.02732 & 0.02342 & 0.01951 & 0.01561 & 0.01171 & 0.00781 & 0.0039 \\
\hline $\mathbf{D A B}_{42}$ & 0.01431 & 0.02083 & 0.01851 & 0.01619 & 0.01388 & 0.01157 & 0.00925 & 0.00695 & 0.00463 & 0.00231 \\
\hline DAB $_{43}$ & 0.03878 & 0.05644 & 0.05017 & 0.04390 & 0.03763 & 0.03136 & 0.02508 & 0.01881 & 0.01254 & 0.00627 \\
\hline DAB $_{44}$ & 0.00563 & 0.00819 & 0.00728 & 0.00637 & 0.00546 & 0.00455 & 0.00364 & 0.00273 & 0.00182 & 0.00092 \\
\hline Total & 1.00000 & 1.00000 & 1.00000 & 1.00000 & 1.00000 & 1.00000 & 1.00000 & 1.00000 & 1.00000 & 1.00000 \\
\hline
\end{tabular}

Table 10: Global rank for sub-barrier according to sensitivity analysis when the weight of datarelated barriers $\left(\mathrm{DAB}_{3}\right)$ is varied from 0.1 to 0.9 .

\begin{tabular}{|c|c|c|c|c|c|c|c|c|c|c|}
\hline Barrier & Normal $(0.3816)$ & 0.1 & 0.2 & 0.3 & 0.4 & 0.5 & 0.6 & 0.7 & 0.8 & 0.9 \\
\hline $\mathbf{D A B}_{11}$ & 4 & 2 & 2 & 2 & 4 & 5 & 5 & 6 & 6 & 6 \\
\hline $\mathrm{DAB}_{12}$ & 1 & 1 & 1 & 1 & 1 & 3 & 3 & 4 & 5 & 5 \\
\hline $\mathbf{D A B}_{13}$ & 10 & 7 & 9 & 10 & 11 & 11 & 11 & 11 & 11 & 11 \\
\hline $\mathbf{D A B}_{21}$ & 7 & 4 & 5 & 6 & 7 & 8 & 8 & 8 & 8 & 8 \\
\hline $\mathbf{D A B}_{22}$ & 5 & 3 & 3 & 5 & 5 & 6 & 7 & 7 & 7 & 7 \\
\hline $\mathbf{D A B}_{23}$ & 8 & 5 & 7 & 8 & 8 & 9 & 9 & 9 & 9 & 9 \\
\hline DAB $_{24}$ & 13 & 11 & 12 & 13 & 13 & 13 & 13 & 13 & 13 & 13 \\
\hline $\mathbf{D A B}_{31}$ & 2 & 8 & 4 & 3 & 2 & 1 & 1 & 1 & 1 & 1 \\
\hline $\mathrm{DAB}_{32}$ & 6 & 13 & 10 & 7 & 6 & 4 & 4 & 3 & 3 & 3 \\
\hline DAB $_{33}$ & 3 & 10 & 6 & 4 & 3 & 2 & 2 & 2 & 2 & 2 \\
\hline DAB $_{34}$ & 11 & 14 & 13 & 11 & 10 & 7 & 6 & 5 & 4 & 4 \\
\hline DAB $_{41}$ & 12 & 9 & 11 & 12 & 12 & 12 & 12 & 12 & 12 & 12 \\
\hline DAB $_{42}$ & 14 & 12 & 14 & 14 & 14 & 14 & 14 & 14 & 14 & 14 \\
\hline $\mathrm{DAB}_{43}$ & 9 & 6 & 8 & 9 & 9 & 10 & 10 & 10 & 10 & 10 \\
\hline DAB $_{44}$ & 15 & 15 & 15 & 15 & 15 & 15 & 15 & 15 & 15 & 15 \\
\hline
\end{tabular}


The weights of sub-barriers and their rankings during sensitivity analysis are presented in Figs. 3 and 4 .

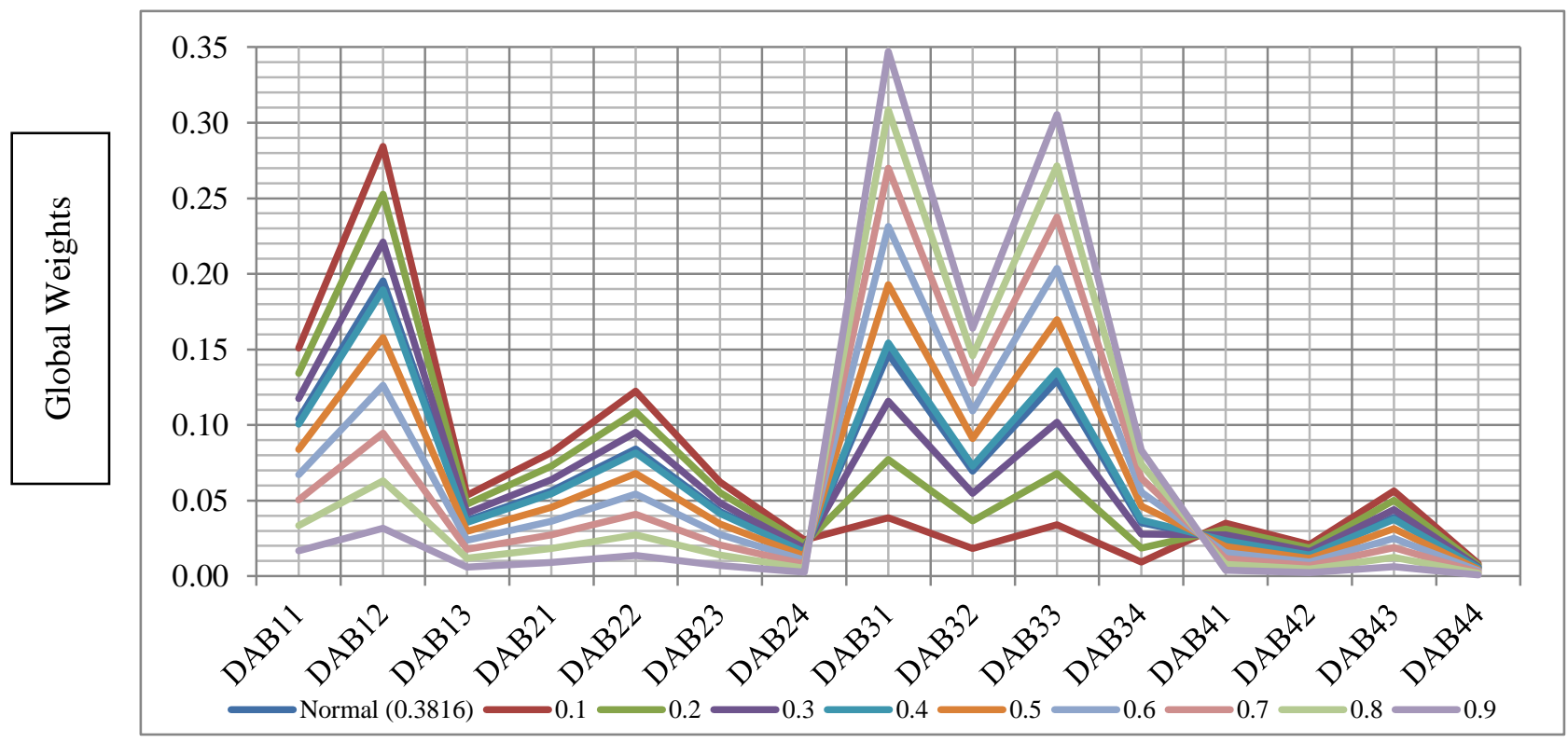

Fig. 3: Sensitivity analysis of barriers to using BDA in manufacturing supply chains (by global weights).

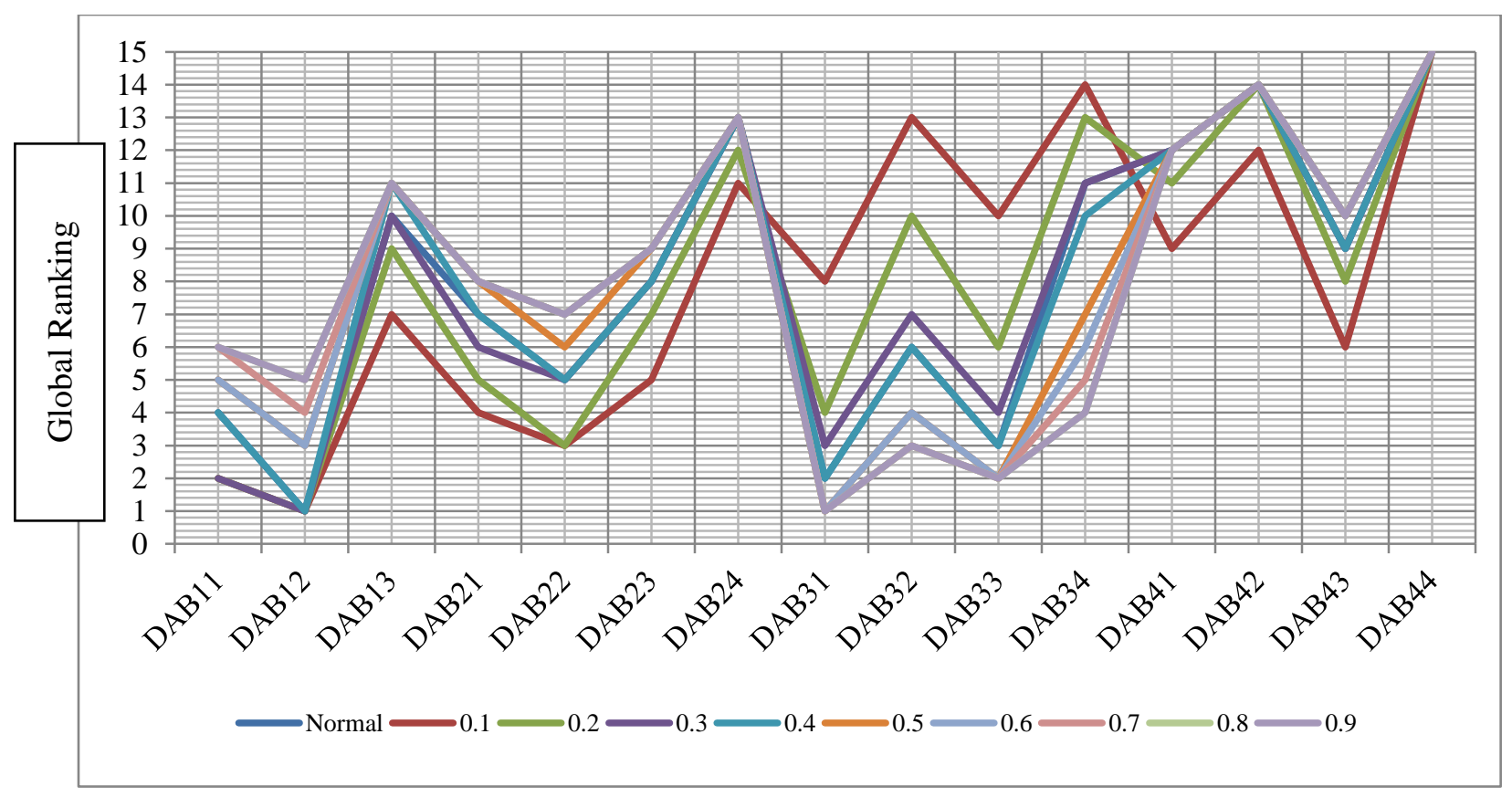

Fig. 4: Sensitivity analysis of barriers to using BDA in manufacturing supply chains (by rank). 
From the sensitivity analysis, we can conclude that data-related barriers $\left(\mathrm{DAB}_{3}\right)$ have high importance among the listed barriers. It therefore warrants greater attention from industrial managers in the adoption of BDA in manufacturing supply chains. It helps decision makers to formulate tactical and strategic decisions regarding the adoption of BDA in manufacturing supply chains.

\section{Managerial implications}

The unique contribution of this research is in the assessment of the barriers to the use of BDA in manufacturing supply chains in Bangladesh. A Delphi-based AHP approach was employed in to quantify each barrier. This study may help industrial mangers to understand the significance of each barrier during the adoption of BDA in their supply chains. Moreover, industrial managers may get a clearer idea of the actual characteristics of these barriers, which may help them to formulate tactical and strategic policies regarding BDA adoption. In addition, this research may assist decision makers in preparing action plans to overcome the hurdles to using BDA. Some important managerial implications of using BDA are also recommended for policy makers and industrial managers. The managerial implications of this research are summarised below:

\section{- Formulating strategic policy regarding BD management in manufacturing supply} chains: In the era of BD, it is difficult to manage and analyse data without BDA tools. Hence, to improve manufacturing performance, it is mandatory to analyse such data. This research helps decision makers to formulate strategic policies regarding the use of BDA in supply chains by considering the barriers we have identified. It is difficult to eradicate barriers without proper strategic policy. This research assists decision makers to understand the actual nature of the barriers.

- Formulating organisational vision and managerial policy to develop technology for BDA: Without improving technological infrastructure, it is not possible to maintain and manage big data derived from supply chains. Therefore, this study has taken into account some technology-related barriers to understand their effects on supply chains. To handle such barriers, managers should formulate BDA policy within their manufacturing supply chains. Industrial managers should also highlight the goal of using BDA tools. This study helps industrial mangers and decision makers to formulate company vision and managerial policy regarding BDA. 
- Expanding funding and arranging training programs to adopt BDA in supply chains: To sustain business in the competitive global market, it is crucial to adopt BDA in manufacturing supply chains. Therefore, managers should give proper attention to securing funds for developing BDA tools and arranging training programs to develop the skills of IT personnel. This research helps to understand the nature of existing barriers, so that industrial managers are motivated to expand funding for BDA tool development.

This study is expected to assist industrial managers to explore the barriers to BDA in manufacturing supply chains in Bangladesh. Upon identifying such barriers, managers can adjust their policies to implement BDA, which can improve supply chain performance.

\section{Conclusions and future research directions}

In the era of $\mathrm{BD}$, many manufacturers in developed countries are starting to adopt BDA tools to improve business performance, smooth production and to minimise risk (H. Chen, Chiang, \& Storey, 2012; Leveling, Edelbrock, \& Otto, 2014; G. Wang et al., 2016b). The adoption of BDA is still in its early stages in Bangladesh. Manufacturers are facing challenges in adopting BDA in manufacturing supply chains. Therefore, this research contributes to the BDA literature by assessing the significance of each barrier using a Delphi-based AHP approach.

Four categories of major barriers and fifteen sub-barriers were considered for analysis using AHP. The findings reveal that data-related barriers were the first-ranked major barrier. Four sub-barriers, namely lack of infrastructural facilities, complexity of data integration, data privacy and lack of availability of BDA tools were found to be the most important barriers to the use of BDA in manufacturing supply chains. After evaluating the barrier rankings, a sensitivity analysis was conducted, which confirmed the stability of the rankings.

In the future, barriers to BDA using international data can be examined. Also, examining the interaction among barriers using the grey-based Decision Making Trial and Evaluation Laboratory (DEMATEL) or interpretive structural modelling (ISM) techniques is worth investigating. Beside AHP technique, this research direction may be explore further by utilizing extension of AHP technique like, fuzzy-AHP, Pythagorean fuzzy AHP \& fuzzy inference system, AHP and AHP and Fine Kinney methodologies, AHP integrated PROMETHEE and VIKOR methods, interval rough AHP and interval rough MABAC methods. This research may 
help manufacturing companies to develop business policies related to BDA in supply chains. It may also lead to the exploration of barriers to BDA in service companies.

\section{References}

Addo-Tenkorang, R., \& Helo, P. T. (2016). Big Data Applications in Operations/Supply-Chain Management: A Literature Review. Computers \& Industrial Engineering, 101, 528-543. https://doi.org/10.1016/j.cie.2016.09.023

Ahmed, E., Yaqoob, I., Hashem, I. A. T., Khan, I., Ahmed, A. I. A., Imran, M., \& Vasilakos, A. V. (2017). The role of big data analytics in Internet of Things. Computer Networks, in press, 1-13. https://doi.org/10.1016/j.comnet.2017.06.013

Alharthi, A., Krotov, V., \& Bowman, M. (2017). Addressing barriers to big data. Business Horizons, 60(3), 285-292. https://doi.org/10.1016/j.bushor.2017.01.002

An, D., Xi, B., Ren, J., Wang, Y., Jia, X., He, C., \& Li, Z. (2017). Sustainability assessment of groundwater remediation technologies based on multi-criteria decision making method. Resources, Conservation and Recycling, 119, 36-46. https://doi.org/10.1016/j.resconrec.2016.08.002

Arunachalam, D., Kumar, N., \& Kawalek, J. P. (2017). Understanding big data analytics capabilities in supply chain management: Unravelling the issues, challenges and implications for practice.

Transportation Research Part E: Logistics and Transportation Review, in press, 1-21. https://doi.org/10.1016/j.tre.2017.04.001

Bai, C., Kusi-Sarpong, S., \& Sarkis, J. (2017). An implementation path for green information technology systems in the Ghanaian mining industry. Journal of Cleaner Production, 164, 1105-1123. https://doi.org/10.1016/j.jclepro.2017.05.151

Beyer, M. a., \& Laney, D. (2012). The Importance of "Big Data": A Definition. Gartner Publications (Vol. i). https://doi.org/G00235055

Bi, Z., \& Cochran, D. (2014). Big data analytics with applications. Journal of Management Analytics, 1(4), 249-265. https://doi.org/10.1080/23270012.2014.992985

Chae, B. (2015). Insights from hashtag \#supplychain and Twitter Analytics: Considering Twitter and Twitter data for supply chain practice and research. International Journal of Production Economics, 165, 247-259. https://doi.org/10.1016/j.ijpe.2014.12.037

Chen, H., Chiang, R. H. L., \& Storey, V. C. (2012). Business Intelligence and Analytics: From Big Data To Big Impact. Mis Quarterly, 36(4), 1165-1188. https://doi.org/10.1145/2463676.2463712

Chen, M., Mao, S., \& Liu, Y. (2014). Big data: A survey. Mobile Networks and Applications, 19(2), 171209. https://doi.org/10.1007/s11036-013-0489-0

Dalkey, N., \& Helmer, O. (1963). An experimental application of the Delphi method to the use of experts. Management Science, 9(3), 458-467.

Davenport, T. H., \& Dyché, J. (2013). Big data in big companies. Baylor Business Review.

Dessureault, S. (2016). Understanding big data. CIM Magazine, 11(1), 33.

Fallik, D. (2014). For big data, big questions remain. Health Affairs, 33(7), 1111-1114. 
https://doi.org/10.1377/hlthaff.2014.0522

Gandomi, A., \& Haider, M. (2015). Beyond the hype: Big data concepts, methods, and analytics. International Journal of Information Management, 35(2), 137-144. https://doi.org/10.1016/j.ijinfomgt.2014.10.007

George, G., Haas, M. R., \& Pentland, A. (2014). Big Data and Management. Academy of Management Journal, 57(2), 321-326. https://doi.org/10.1111/risa.12257

Gordon, T. J. (2009). The Delphi Method. Futures Research Methodology v3.0 [CD-ROM], 1-29.

Gottfried, O., Clercq, D. De, Blair, E., Weng, X., \& Wang, C. (2018). SWOT-AHP-TOWS analysis of private investment behavior in the Chinese biogas sector. Journal of Cleaner Production, 184, 632647. https://doi.org/https://doi.org/10.1016/j.jclepro.2018.02.173

Govindan, K., Kaliyan, M., Kannan, D., \& Haq, A. N. (2014). Barriers analysis for green supply chain management implementation in Indian industries using analytic hierarchy process. International Journal of Production Economics, 147(PART B), 555-568. https://doi.org/10.1016/j.ijpe.2013.08.018

Hazen, B. T., Skipper, J. B., Ezell, J. D., \& Boone, C. A. (2016). Big data and predictive analytics for supply chain sustainability: A theory-driven research agenda. Computers \& Industrial Engineering, 101, 592-598. https://doi.org/10.1016/j.cie.2016.06.030

Hilbert, M. (2016). Big Data for Development: A Review of Promises and Challenges. Development Policy Review, 34(1), 135-174. https://doi.org/10.1111/dpr.12142

Hsu, C., \& Sandford, B. (2007). The delphi technique: making sense of consensus. Practical Assessment, Research \& Evaluation, 12(10), 1-8. https://doi.org/10.1016/S0169-2070(99)00018-7

Ilbahar, E., Karaşan, A., Cebi, S., \& Kahraman, C. (2018). A novel approach to risk assessment for occupational health and safety using Pythagorean fuzzy AHP \& fuzzy inference system. Safety Science, 103, 124-136. https://doi.org/10.1016/j.ssci.2017.10.025

Jaberidoost, M., Olfat, L., Hosseini, A., Kebriaeezadeh, A., Abdollahi, M., Alaeddini, M., \& Dinarvand, R. (2015). Pharmaceutical supply chain risk assessment in Iran using analytic hierarchy process (AHP) and simple additive weighting (SAW) methods. Journal of Pharmaceutical Policy and Practice, 8(9), 1-10. https://doi.org/10.1186/s40545-015-0029-3

Kwon, O., Lee, N., \& Shin, B. (2014). Data quality management, data usage experience and acquisition intention of big data analytics. International Journal of Information Management, 34(3), 387-394. https://doi.org/10.1016/j.ijinfomgt.2014.02.002

Kokangül, A., Polat, U., \& Dağsuyu, C. (2017). A new approximation for risk assessment using the AHP and Fine Kinney methodologies. Safety Science, 91, 24-32. https://doi.org/10.1016/j.ssci.2016.07.015

Lee, I. (2017). Big data: Dimensions, evolution, impacts, and challenges. Business Horizons, 60(3), 293303. https://doi.org/10.1016/j.bushor.2017.01.004

Leveling, J., Edelbrock, M., \& Otto, B. (2014). Big data analytics for supply chain management. In 2014 IEEE International Conference on Industrial Engineering and Engineering Management (IEEM) (pp. 918-922). Bandar Sunway, Malaysia. https://doi.org/10.1109/IEEM.2014.7058772 
Li, J., Tao, F., Cheng, Y., \& Zhao, L. (2015). Big Data in product lifecycle management. The International Journal of Advanced Manufacturing Technology, 81(1-4), 667-684. https://doi.org/10.1007/s00170-015-7151-x

Linstone, H. A., \& Turoff, M. (1975). The Delphi method: Techniques and applications (Vol. 29). Addison-Wesley Reading, MA.

Lummus, R. R., Vokurka, R. J., \& Duclos, L. K. (2005). Delphi study on supply chain flexibility. International Journal of Production Research, 43(13), 2687-2708. https://doi.org/10.1080/00207540500056102

Maalouf, M., \& Gammelgaard, B. (2016). Managing paradoxical tensions during the implementation of lean capabilities for improvement. International Journal of Operations \& Production Management, 36(6), 687-709. https://doi.org/10.1108/IJOPM-10-2014-0471

Madaan, J., \& Mangla, S. (2015). Decision Modeling Approach for Eco-Driven Flexible Green Supply Chain. In Systemic Flexibility and Business Agility (pp. 343-364). Springer India. https://doi.org/10.1007/978-81-322-2151-7_21

Malaka, I., \& Brown, I. (2015a). Challenges to the Organisational Adoption of Big Data Analytics. In Proceedings of the 2015 Annual Research Conference on South African Institute of Computer Scientists and Information Technologists - SAICSIT'15 (pp. 1-9). https://doi.org/10.1145/2815782.2815793

Malaka, I., \& Brown, I. (2015b). Challenges to the Organisational Adoption of Big Data Analytics : A Case Study in the South African Telecommunications Industry. In Proceedings of the 2015 Annual Research Conference on South African Institute of Computer Scientists and Information Technologists (pp. 1-9). Stellenbosch, South Africa: ACM, New York. https://doi.org/10.1145/2815782.2815793

Mangla, S. K., Govindan, K., \& Luthra, S. (2017). Prioritizing the barriers to achieve sustainable consumption and production trends in supply chains using fuzzy Analytical Hierarchy Process. Journal of Cleaner Production, 151, 509-525. https://doi.org/10.1016/j.jclepro.2017.02.099

Minelli, M., Chambers, M., \& Dhiraj, A. (2013). Big Data, Big Analytics: Emerging Business Intelligence and Analytic Trends for Today's Businesses. Big Data, Big Analytics: Emerging Business Intelligence and Analytic Trends for Today's Businesses. New Jersey: John Wiley \& Sons. https://doi.org/10.1002/9781118562260

Murry, J. W., \& Hammons, J. O. (1995). Delphi: A Versatile Methodology for Conducting Qualitative Research. The Review of Higher Education, 18(4), 423-436. https://doi.org/10.1353/rhe.1995.0008

Okoli, C., \& Pawlowski, S. D. (2004). The Delphi method as a research tool: an example, design considerations and applications. Information \& Management, 42(1), 15-29.

Pamučar, D., Stević, Ž., \& Zavadskas, E. K. (2018). Integration of interval rough AHP and interval rough MABAC methods for evaluating university web pages. Applied Soft Computing, 67, 141-163. https://doi.org/https://doi.org/10.1016/j.asoc.2018.02.057

Paleie, I., \& Lalic, B. (2009). Analytical hierarchy process as a tool for selecting and evaluating projects. International Journal of Simulation Modelling, 8(1), 16-26. https://doi.org/10.2507/IJSIMM08(1)2.112 
Philip Chen, C. L., \& Zhang, C. Y. (2014). Data-intensive applications, challenges, techniques and technologies: A survey on Big Data. Information Sciences, 275, 314-347.

https://doi.org/10.1016/j.ins.2014.01.015

Rousseaux, F. (2017). BIG DATA and Data-Driven Intelligent Predictive Algorithms to support creativity in Industrial Engineering. Computers \& Industrial Engineering, 112, 459-465. https://doi.org/10.1016/j.cie.2016.11.005

Saaty, T. L. (1988). What is the analytic hierarchy process? In Mathematical models for decision support (pp. 109-121). Springer, Berlin, Heidelberg. https://doi.org/10.1007/978-3-642-83555-1_5

Saaty, T. L. (2008). Decision making with the analytic hierarchy process. International Journal of Services Sciences, 1(1), 83. https://doi.org/10.1504/IJSSCI.2008.017590

Sagiroglu, S., \& Sinanc, D. (2013). Big data: A review. In 2013 International Conference on Collaboration Technologies and Systems (pp. 42-47). San Diego, CA, USA: IEEE. https://doi.org/10.1109/CTS.2013.6567202

Sarmiento, R., \& Thomas, A. (2010). Identifying improvement areas when implementing green initiatives using a multitier AHP approach. Benchmarking: An International Journal, 17(3), 452-463. https://doi.org/10.1108/14635771011049399

Schoenherr, T., Rao Tummala, V. M., \& Harrison, T. P. (2008). Assessing supply chain risks with the analytic hierarchy process: Providing decision support for the offshoring decision by a US manufacturing company. Journal of Purchasing and Supply Management, 14(2), 100-111. https://doi.org/10.1016/j.pursup.2008.01.008

Schoenherr, T., \& Speier-Pero, C. (2015). Data science, predictive analytics, and big data in supply chain management: Current state and future potential. Journal of Business Logistics, 36(1), 120-132. https://doi.org/10.1111/jbl.12082

Sennaroglu, B., \& Varlik Celebi, G. (2018). A military airport location selection by AHP integrated PROMETHEE and VIKOR methods. Transportation Research Part D: Transport and Environment, 59, 160-173. https://doi.org/10.1016/j.trd.2017.12.022

Seuring, S., \& Müller, M. (2008). Core issues in sustainable supply chain management - A Delphi study. Business Strategy and the Environment, 17(8), 455-466. https://doi.org/10.1002/bse.607

Shahin, A., \& Mahbod, M. A. (2007). Prioritization of key performance indicators: An integration of analytical hierarchy process and goal setting. International Journal of Productivity and Performance Management, 56(3), 226-240. https://doi.org/10.1108/17410400710731437

Singh, A., Shukla, N., \& Mishra, N. (2017). Social media data analytics to improve supply chain management in food industries. Transportation Research Part E: Logistics and Transportation Review. https://doi.org/10.1016/j.tre.2017.05.008

Sirisawat, P., \& Kiatcharoenpol, T. (2018). Fuzzy AHP-TOPSIS approaches to prioritizing solutions for reverse logistics barriers. Computers \& Industrial Engineering, 117, 303-318. https://doi.org/https://doi.org/10.1016/j.cie.2018.01.015

Sun, E. W., Chen, Y. T., \& Yu, M. T. (2015). Generalized optimal wavelet decomposing algorithm for big financial data. International Journal of Production Economics, 165, 194-214. 
https://doi.org/10.1016/j.ijpe.2014.12.033

Sivarajah, U., Kamal, M. M., Irani, Z., \& Weerakkody, V. (2017). Critical analysis of Big Data challenges and analytical methods. Journal of Business Research, 70, 263-286. https://doi.org/10.1016/j.jbusres.2016.08.001

Trelles, O., Prins, P., Snir, M., \& Jansen, R. C. (2011). Big data, but are we ready? Nature Reviews Genetics, 12(3), 224-224. https://doi.org/10.1038/nrg2857-c1

Tsai, C.-W. W., Lai, C.-F. F., Chao, H.-C. C., \& Vasilakos, A. V. (2015). Big data analytics : a survey. Journal of Big Data, 2(October), 1-32. https://doi.org/10.1186/s40537-015-0030-3

Waller, M. A., \& Fawcett, S. E. (2013). Data science, predictive analytics, and big data: A revolution that will transform supply chain design and management. Journal of Business Logistics, 34(2), 77-84. https://doi.org/10.1111/jbl.12010

Wang, G., Gunasekaran, A., Ngai, E. W. T., \& Papadopoulos, T. (2016a). Big data analytics in logistics and supply chain management: Certain investigations for research and applications. International Journal of Production Economics. https://doi.org/10.1016/j.ijpe.2016.03.014

Wang, G., Gunasekaran, A., Ngai, E. W. T., \& Papadopoulos, T. (2016b). Big data analytics in logistics and supply chain management: Certain investigations for research and applications. International Journal of Production Economics, 176, 98-110. https://doi.org/10.1016/j.ijpe.2016.03.014

Wang, Y., \& Hajli, N. (2017). Exploring the path to big data analytics success in healthcare. Journal of Business Research, 70, 287-299. https://doi.org/10.1016/j.jbusres.2016.08.002

Wang, Y., Kung, L. A., \& Byrd, T. A. (2016). Big data analytics: Understanding its capabilities and potential benefits for healthcare organizations. Technological Forecasting and Social Change, in press, 1-11. https://doi.org/10.1016/j.techfore.2015.12.019

Wang, Y., Kung, L., Wang, W. Y. C., \& Cegielski, C. G. (2017). An integrated big data analytics-enabled transformation model: Application to health care. Information \& Management, in press, 1-16. https://doi.org/10.1016/j.im.2017.04.001

Xu, Z., Frankwick, G. L., \& Ramirez, E. (2016). Effects of big data analytics and traditional marketing analytics on new product success: A knowledge fusion perspective. Journal of Business Research, 69(5), 1562-1566. https://doi.org/10.1016/j.jbusres.2015.10.017

Zhong, R. Y., Newman, S. T., Huang, G. Q., \& Lan, S. (2016). Big Data for supply chain management in the service and manufacturing sectors: Challenges, opportunities, and future perspectives. Computers \& Industrial Engineering, 101, 572-591. https://doi.org/10.1016/j.cie.2016.07.013 


\section{Appendix - 1}

Table A1: Pairwise assessment matrix for expertise- and investment-related barriers $\left(\mathrm{DAB}_{2}\right)$ to using BDA in manufacturing supply chains

\begin{tabular}{|c|c|c|c|c|c|c|}
\hline $\mathrm{DAB}_{2}$ & $\mathrm{DAB}_{21}$ & $\mathrm{DAB}_{22}$ & $\mathrm{DAB}_{23}$ & $\mathrm{DAB}_{24}$ & Relative weight & Rank \\
\hline $\mathrm{DAB}_{21}$ & 1 & 1 & 1 & 3 & 0.2818 & 2 \\
\hline $\mathrm{DAB}_{22}$ & 1 & 1 & 3 & 5 & 0.4214 & 1 \\
\hline $\mathrm{DAB}_{23}$ & 1 & $1 / 3$ & 1 & 3 & 0.2141 & 3 \\
\hline $\mathrm{DAB}_{24}$ & $1 / 3$ & $1 / 5$ & $1 / 3$ & 1 & 0.0827 & 4 \\
\hline
\end{tabular}

$\lambda_{\max }=4.14097 ; \mathrm{CI}=0.04699 ; \mathrm{CR}=0.05221<0.1$

Table A2: Pairwise assessment matrix for data-related barriers $\left(\mathrm{DAB}_{3}\right)$ to using BDA in manufacturing supply chains

\begin{tabular}{|c|c|c|c|c|c|c|}
\hline $\mathrm{DAB}_{3}$ & $\mathrm{DAB}_{31}$ & $\mathrm{DAB}_{32}$ & $\mathrm{DAB}_{33}$ & $\mathrm{DAB}_{34}$ & Relative weight & Rank \\
\hline $\mathrm{DAB}_{31}$ & 1 & 2 & 1 & 5 & 0.3856 & 1 \\
\hline $\mathrm{DAB}_{32}$ & $1 / 2$ & 1 & $1 / 3$ & 3 & 0.1823 & 3 \\
\hline $\mathrm{DAB}_{33}$ & 1 & 3 & 1 & 2 & 0.3394 & 2 \\
\hline $\mathrm{DAB}_{34}$ & $1 / 5$ & $1 / 3$ & $1 / 2$ & 1 & 0.0927 & 4 \\
\hline
\end{tabular}

$\lambda_{\max }=4.17682 ; \mathrm{CI}=0.05894 ; \mathrm{CR}=0.06549<0.1$

Table A3: Pairwise assessment matrix for organisational barriers $\left(\mathrm{DAB}_{4}\right)$ to using $\mathrm{BDA}$ in manufacturing supply chains

\begin{tabular}{|c|c|c|c|c|c|c|}
\hline $\mathrm{DAB}_{4}$ & $\mathrm{DAB}_{41}$ & $\mathrm{DAB}_{42}$ & $\mathrm{DAB}_{43}$ & $\mathrm{DAB}_{44}$ & Relative weight & Rank \\
\hline $\mathrm{DAB}_{41}$ & 1 & 3 & $1 / 2$ & 3 & 0.2913 & 2 \\
\hline $\mathrm{DAB}_{42}$ & $1 / 3$ & 1 & $1 / 3$ & 5 & 0.1727 & 3 \\
\hline $\mathrm{DAB}_{43}$ & 2 & 3 & 1 & 5 & 0.4681 & 1 \\
\hline $\mathrm{DAB}_{44}$ & $1 / 3$ & $1 / 5$ & $1 / 5$ & 1 & 0.0680 & 4 \\
\hline
\end{tabular}

$\lambda_{\max }=4.21452 ; \mathrm{CI}=0.07151 ; \mathrm{CR}=0.07945<0.1$ 